\title{
FAKTOR FAKTOR SUKSES PENERAPAN KPBU SEBAGAI SUMBER PEMBIAYAAN INFRASTRUKTUR : SUATU KAJIAN
}

\section{Joubert B. Maramis}

Fakultas Ekonomi dan Bisnis, Universitas Sam Ratulangi

$$
\text { A R T I C LE I N F O }
$$

Keywords : KPBU,PPP, infrastrucktur, success, implementation

Kata Kunci : $K P B U, P P P$, infrastruktur, faktor

faktor sukses, implementasi

Corresponding author :

Joubert B. Maramis

rudijbm9792@gmail.com
Abstrack :Currently, the Government of Indonesia under President RI Joko Widodo (Jokowi), focused to build Indonesia through infrastructure development. Infrastructure in Regulation 38/2015 article 5 can be economic and social infrastructure. From the results of the above discussion can be summed up some basic IE (1) KPBU or PPP is the form the cooperation of Government and business entities in the provision of infrastructure (2) basic characteristics of KPBU is a long term cooperation, sharing of risk between the parties and the parties to produce a product (goods or services). (3) In Indonesia, the type of infrastructure can be done KPBU is the economic and social infrastructure. (4) the form of KPBU or PPP theoretically vary widely ranging from) Service Contract and Management Contract to the Private Finance Initiative and Private ownership along with the form of derivatives. (5) the determinants of success factors for implementation of $K P B U$ can be: the ability of the Government, institutional KPBU Komprehensip In KPBU, in Exchange for private parties, legal certainty and Opportunistic Behavior.

Abstrak : Saat ini, pemerintah Indonesia dibawah Presiden RI Joko Widodo (Jokowi), berfokus untuk membangun Indonesia melalui pembangunan infrastruktur. Infrastruktur dalam Perpres 38 / 2015 Pasal 5 dapat berupa infrastruktur ekonomi dan sosial. Dari hasil bahasan diatas dapat disimpulkan beberapa hal pokok yaitu (1) KPBU atau PPP adalah bentuk kerjasama pemerintah dan badan usaha dalam penyediaan infrastruktur (2) karakteristik dasar KPBU adalah kerjasama jangka panjang, saling membagi resiko antar para pihak dan para pihak menghasilkan produk (barang atau jasa). (3) Di Indonesia, jenis infrastruktur yang bisa dilakukan KPBU adalah infrastruktur ekonomi dan sosial. (4) Bentuk KPBU atau PPP secara teoritis sangat bervariasi mulai dari) Service Contract and Management Contract sampai pada Private Finance Initiative and Private ownership berserta bentuk turunannya. (5) Faktor faktor penentu kesuksesan implementasi KPBU dapat berupa : Kemampuan Komprehensip KPBU Pemerintah, Kelembagaan Dalam KPBU, Imbalan Bagi Pihak Swasta Yang Menarik, Kepastian Hukum dan Perilaku Oportunistik. 


\section{Latar Belakang}

\section{PENDAHULUAN}

Saat ini, pemerintah Indonesia dibawah Presiden RI Joko Widodo (Jokowi), berfokus untuk membangun Indonesia melalui pembangunan infrastruktur. Beberapa tahun belakangan ini pemerintah terus mengenjot pembangunan infrastruktur di seluruh Indonesia. Jalan tol, pelabuhan laut, pelabuhan udara, waduk atau bendungan, jalan nasional, jalan kereta api dan jenis infrastruktur lainnya. Juga dibangun kawasan hinterlandnya baik berupa pusat pusat industri, kawasan industri maupun Kawasan Ekonomi Khusus. Infrastruktur dan pengembangan kawasan industri dibangun dengan satu tujuan agar Indonesia memiliki daya saing tinggi di kemudian hari.

Infrastruktur dalam arti luas, pada dasarnya dapat dibagi menjadi tiga jenis. Pertama, infrastruktur publik adalah infrastruktur yang tidak berbayar dan dapat dinikmati oleh seluruh warga negera. Misalnya : jalan umum, jembatan, waduk atau bendungan, irigasi dan fasilitas publik lainnya. Kedua, infrastruktur semi private adalah infrastruktur atau fasilitas yang berbayar namun tidak berorientasi pada profit oriented. Biasanya infrastruktur ini dikelola oleh pemerintah. Misalnya : listrik (PLN), gedung atau fasilitas kesenian, objek wisata umum dan sejenisnya. Pengguna fasilitas ini biasanya dikenai tarif atau restribusi yang rendah. Ketiga, infrastruktur private adalah infrastruktur atau fasilitas yang berorientasi profit. Misalnya : jalan tol, pelabuhan laut, bandar udara, kawasan industri, Kawasan Ekonomi Khusus (KEK) dan sejenisnya. Jenis infrastruktur pertama biasanya dibangun oleh pemerintah. Namun untuk infrastruktur kedua dan ketiga biasanya oleh BUMN atau BUMD, Swasta atau kerjasama.

Salah satu permasalahan mendasar di Indonesia adalah ketimpangan infrastruktur (baik infrastruktur publik, semi publik maupun private). Ketimpangan ini dapat dilihat dari sisi kewilayahan. Indonesia bagian barat, memiliki infrastruktur yang lebih banyak di banding Indonesia Bagian Timur. Penumpukan penduduk dan industri di Indonesia Bagian Barat membuat konsentrasi ekonomi dan infrastruktur lebih banyak di bangun di Indonesia bagian barat (Jawa, Sumatera dan Bali). Di samping sisi kuantitas, sisi kualitas juga mengalami ketimpangan. Infrastruktur di Indonesia bagian Barat lebih lengkap dan maju dibanding dengan yang ada di Indonesia Bagian Timur.

Salah satu masalah besar dalam hal pembangunan infrastruktur adalah masalah pembiayaan. Meningkatnya kebutuhan akan KPBU dalam konteks pembiayaan infrastruktur disebabkan oleh beberapa faktor yaitu adanya urbanisasi dan kurangnya dana pemerintah (Jin, 2009). Infrastruktur yang dibangun, bukan hanya bersifat barang publik namun juga barang semi publik maupun barang private. Untuk membangun, mengoperasikan dan memelihara fasilitas fasilitas ini, dibutuhkan uang atau modal yang sangat besar. Dan sampai saat ini, kebutuhan modal untuk pembiayaan infrastruktur ini, tidak mampu dicover oleh Pemerintah Republik Indonesia sendiri. Untuk itu, fokus kebijakan Presiden Jokowi adalah dengan melibatkan BUMN khususnya pada proyek proyek yang memiliki tingkat pengembalian modal yang kecil atau proyek proyek yang tidak atau kurang diminati oleh swasta.

Pada dasarnya keterlibatan pemerintah dalam pembiayaan infrastruktur ada dua bentuk yaitu pembiayaan langsung dari APBN atau APBD untuk infrastruktur publik dan melalui BUMN atau BUMD (baik penyertaan modal atau kebijakan penggunaan modal BUMD atau BUMD dalam menunjang program program pemerintah atau pemerintah daerah). Untuk BUMD atau BUMD, mereka dapat masuk ke pembiayaan infrastruktur semi publik dan private. Namun dilema besar bagi BUMN dan BUMD adalah sifat institusi bisnisnya. Itu berarti bahwa mereka harus menciptakan profit. Namun menurut Nsasira et al (2013) ada satu kelemahan dalam BUMD / BUMN yaitu masalah ketidakefisienan. Salah satu solusinya adalah dengan membangun kerjasama pembiayaan, pembangunan, pengoperasian dan pemeliharaan infrastruktiur atau fasilitas semi publik dan private dengan pihak swasta.

Menjawab permasalahan akan kurangnya dana pemerintah tersebut maka dikeluarkan Perpres 38 / 2015 dan Permen PPN no 4 / 2015 yang terkait dengan KPBU (Kerjasama Pemerintah dan Badan Usaha). Istilah KPBU sama dengan terminologi PPP (Public Private Partnership), jadi pada tulisan ini akan disamakan konsep KPBU dan PPP. Namun banyak hasil penelitian di luar negeri, yang menunjukkan adanya kesuksesan dan kegagalan dalam KPBU ini. Sukses dan gagal KPBU disebabkan oleh banyak faktor dan karakteristik yang bervariasi antar negara. Faktor ini dari aspek teknis atau aplikasi seperti menurut Carbonara et al (2013) bahwa aplikasi PPP sangat bervariasi antar negara, dari sektor ke sektor dan dari proyek ke proyek. Sampai pada aspek filosofis seperti yang dikatakan Nsasira et al, (2013). Ia mengatakan bahwa kritik PPP terletak pada ketakutan akan privatisasi, bahwa pemerintah secara efektif akan menggadaikan masa depan. Juga pemerintah ditakutkan akan membayar biaya yang lebih tinggi pada sektor swasta dalam jangka panjang dibanding dengan jika fasilitas PPP tersebut dibangun pemerintah. Berdasarkan diskusi diatas maka tulisan ini akan difokuskan pada faktor faktor sukses penerapan KPBU sebagai sumber 
pembiayaan infrastruktur di Indonesia. Untuk lebih detail pembahasan akan dikembangkan pada pertanyaan utama seperti : apa itu KPBU, jenis infrastruktur apa yang bisa dilakukan dengan skema KPBU di Indonesia, bentuk bentuk skema KPBU, dan faktor faktor sukses implementasi KPBU di Indonesia.

\section{Teori Teori Terkait PPP}

\section{TINJAUAN PUSTAKA}

\section{Transaction Cost Economics Theory (TCET)}

Menurut Qu and Loosemore (2013), teori ini dapat menerangkan perilaku oportunistik, yang bisa terjadi antar partner dalam kontrak PPP. Teori ini menyatakan bahwa perilaku oportunistik bisa terjadi karena kedua belah pihak memiliki hubungan yang saling mengunci (terikat dengan kontrak). Ada tiga elemen penting dalam TCET yang bisa menjelaskan perilaku oportunistik yaitu : asset specificity, environmental uncertainty and imperfect control.

Asset specificity. Elemen kekhususan asset ini, pada dasarnya ingin menyatakan bahwa transaksi yang bersifat "durable transaction-specific investments", tidak mungkin digunakan untuk tujuan lain tanpa adanya kerugian financial antar pihak dalam PPP. Sifat asset ini menjadi hambatan para pihak untuk keluar dari suatu hubungan kerjasama. Semakin besar asset ini semakin rugi para pihak jika bersifat opportunistik. Artinya ada biaya yang lebih besar yang ditanggung oleh para pihak jika tidak melanjutkan kontrak ketimbang melanjutkannya. Dan jika salah satu pihak mengetahui pihak lain berkomitment meneruskan hubungan ini tampa adanya peningkatan biaya maka akan ada peluang untuk berperilaku opportunistik. Jadi berdasarkan prinsip Asset specificity, maka agar kolaborasi atau kerjasama optimal dan efisien dalam PPP maka perlu ditentukan dan disepakati secara bersama sama kaidah, norma atau batasan serta mekanisme kerja yang optimal dan efisien antar pihak sehingga kontrak PPP akan mewujudkan "kesejajaran kepentingan" antar kedua belah pihak. Jika tidak, maka sekali terikat dalam kontrak maka sulit untuk keluar dari kontrak tersebut tampa kedua belah pihak menanggung biaya yang signifikan.

Environmental uncertainty and imperfect control. Ketidakpastian lingkungan didasari pada asumsi dasar TCET yaitu bounded rationality (asumsi rasional terbatas). Asumsi ini merupakan bentuk semi kuat dari rasionalitas namun terbatas untuk ketidakpastian. Ketidakpastian ini akan menghasilkan resiko. Dari sisi hakikat resiko, tidak mungkin resiko bisa dihilangkan. Resiko hanya dapat ditransfer atau diminimalkan. Resiko bisa meningkat jika para pihak tidak punya kemampuan atau pemahaman serta pengendalian yang penuh. Apalagi jika faktor determinan resiko berada diluar kontrol para pihak dalam PPP. Semakin tinggi ketidakpastian, semakin tinggi ketidakmampuan dalam mengontrol maka semakin besar kemungkinan terjadinya perilaku opportunistik dari para pihak dalam PPP.

Berdasarkan prinsip keberadaan Environmental uncertainty maka kontrak PPP seharusnya mempertajam kriteria pemilihan pihak yang mau terlibat dalam kontrak PPP, membuat kontrak PPP lebih transparan, melalui proses negoisasi yang lebih detail, mengembangkan penilaian penilaian dari pihak profesional sehingga kontrak PPP mampu meminimalkan ketidakpastian atau resiko yang bisa terjadi karena aspek lingkungan dimasa depan.

Pendapat lain oleh Nsasira et al, (2013) yang mengambil transaction cost theory dari pemikiran Coase (1937). Intinya bahwa pada dasarnya organisasi mengevaluasi biaya relatif dari alternatif struktur governance, seperti biaya : transaksi pasar spot, kontrak jangka menengah dan panjang serta integrasi vertikal, untuk mengelola transaksi. Teori ini juga menyatakan bahwa setiap kesepakatan kontraktual mengandung biaya yang harus ditanggung dalam proses negoisasi dan penandatanganannya untuk memonitor kinerja pihak lain dan untuk memperkuat kontrak tersebut. Selanjutnya dikatakan bahwa biaya transaksi akan relevan ketika hubungan bersifat rutin (berulang ulang), adanya ketidakpastian dan atau adanya specific assets. Nsasira et al, (2013) juga menyatakan bahwa teori TCET ini dikritik karena (1) mengabaikan power relation (2) mengabaikan kepercayaan (trust) dan social emeddedness (3) pemikiran pemikiran evolusi seperti perubahan dalam proses pasar seperti peranan outsourcing.

\section{Stakeholders Theory (ST)}

Menurut Nsasira et al, (2013), teori ini diusulkan oleh Freeman (1984) dan penerapan teori ini dalam proyek PPP dikembangkan oleh Ke and Wang (2009). Teori ini digunakan untuk menjadi dasar dalam pemilihan kriteria pengambilan keputusan dalam proyek PPP. Teori ini lebih berfokus pada tahapan pemilihan proyek-proyek yang akan dimasukkan dalam proposal PPP. Di Indonesia tahapan ini masuk dalam kegiatan konsultasi publik atas 
proyek proyek PPP. Teori ini berperan dapak menganalisis permintaan proyek PPP untuk bermacam macam stakeholder. Teori ini akan membantu dalam menentukan proporsional laba yang bisa diambil pelaksana PPP dibandingkan dengan investasi yang ditanamkan dan resiko yang ditanggung. Kemudian teori ini juga dapat digunakan dalam hal monitoring atau pengawasan ketika proyek PPP sedang berjalan. Teori ini menyatakan bahwa monitoring atau pengawasan akan optimal atau efisien jika pengawasan melibatkan semua stakeholders.

\section{Agency Theory (AT)}

Di dalam artikel $\mathrm{Qu}$ and Loosemore (2013), agency theory (AT) bertolak belakang dengan TCET (transaction cost economic theory). Kalau pada TCET kontrak belum komplit maka pada AT kontrak diasumsikan telah komplit. AT mengasumsikan bahwa baik agent dan prinsipal bersifat rasional dan memiliki kepentingan pribadi (self-interested). Untuk kesamaan antara AT dan TCET adalah aspek rasional terbatas namun pada AT rasional terbatas ini atas ketidaksimetrisan informasi (information asymmetry) antar pihak. Ketidaksimetrisan informasi (salah satu pihak mengetahui sedangkan pihak lain tidak atau pihak lain memiliki informasi yang superior sedangkan yang lain tidak) akan menciptakan perilaku oportunis. Juga dalam AT menyebabkan adverse selection atau moral hazard. Ketika salah satu partner memiliki motif untuk menipu dan partner tersebut memiliki keunggulan informasi relatif terhadap pihak lain dalam suatu hubungan maka pihak tersebut memiliki peluang yang baik untuk melakukan apa yang ia inginkan.

Teori ini bisa menjawab beberapa tidak optimalnya kontrak Proyek PPP. Misalnya : untuk suatu proyek PPP, masyarakat tidak mengetahui dengan detail kualifikasi pelaksana atau pembangun dan tidak mendapatkan informasi detail atas dokumen penawaran. Dalam konteks ini maka pelaksana dapat melakukan perilaku oportunistik karena masyarakat tidak memiliki informasi lengkap (terdapat assymetric information).

\section{Delinquency Theory / Teori kenakalan (DT)}

$\mathrm{Qu}$ and Loosemore (2013) menyatakan bahwa Transaction Cost Economics Theory (TCET) Dan Agency Theory (AT) bertujuan untuk menerangkan "kondisi dimana perilaku oportunistik itu terjadi". Kedua teori ini membantu dalam menjawab pertanyaan-pertanyaan seperti : akankah orang bertindak oportunistik jika mereka tahu mereka salah dan tindakan salah / oportunistik mereka akan dijatuhi hukum ? Namun dalam Delinquency Theory (DT) lebih berfokus pada bagaimana mereka membenarkan perilaku oportunistik (membenarkan kesalahan) mereka. Selanjutnya Qu and Loosemore (2013) menyatakan bermain netral adalah lakon / sandiwara penting dalam membenarkan tindakan salah mereka. Mereka menggunakan pendapat Sykes and Matza (1957) untuk menganalisis orang melakukan pembenaran atas tindakan salah yaitu aspek externalization, normalization and superordination.

Externalization. Externalization merupakan situasi dimana tindakan dari pelanggar (tindakan oportunistik pribadinya) dianggap benar karena berada diluar kemampuan dan diluar kontrolnya. Dalam aspek ini, pelanggar biasanya akan membenarkan tanggungjawab mereka atas berperilaku oportunistik dengan cara-cara : menyalahkan ketidakpastian lingkungan, kontrol dari pihak lain yang tidak sempurna, adanya asymmetric information dan asset specificity dari pihak lain. Intinya, orang ini akan membenarkan tindakan salahnya dengan menyalahkan kondisi lingkungan (eksternal) yang berada di luar kendalinya. Tanggungjawab pelanggar (orang yang membenarkan tindakan salahnya) terhadap tindakan salahnya akan ia benarkan dengan alasan : (a) jika kerugian disebabkan oleh ketidakpastian (b) jika kerugian disebabkan oleh adanya informasi tidak simetris antara pihak (c) jika kerugian disebabkan oleh adanya asset specificity dari pihak lainnya. Alasan alasan ini menjadi argumen kuat dari pelanggar untuk membenarkan tindakan salahnya (perilaku oportunistiknya). Contoh : walaupun orang atau pihak tidak perlu menanggung resiko ekstra apabila mereka memutuskan suatu hubungan atau kontrak, namun ia tetap memilih untuk mempertahankan hubungan atau kontrak dengan rekan kerjanya karena adanya jutaan dollar investasi yang menjadi tanggungjawabnya. Tindakan orang atau pihak ini masuk kategori oportunistik behavior (menurut Transaction Cost Economics Theory (TCET) Dan Agency Theory (AT), namun motif atau alasannya untuk mempertahankan kontrak masuk dalam lingkup Delinquency Theory (DT).

Normalization. Normalization digambarkan sebagai orang yang membenarkan tindakan salah mereka sebagai hal yang normal (wajar wajar saja). Contoh : karena hal biasa disuatu negara, misalnya karakteristik industri kontruksinya yang reputasi jelek dalam komitmen maka dianggap wajar jika melanggar komitmen dalam proyek PPP. Ini berarti juga adalah hal wajar untuk melakukan negoisasi ulang (baik waktu, volume atau biaya) suatu proyek. Superordination. Superordination adalah membenarkan balas dendam (pembenaran atas hukuman yang 
diberikan). Daelam konteks ini, bahkan jika suatu pihak menerima tindakan mereka bisa menyebabkan kerugian atau luka pada pihak lain, tapi karena kejengkelan atau kemarahan, pihak tersebut akan tetap berpegang bahwa kerugian yang diberikan kepada pihak lain, itu tidak salah. Dalam kasus ini, kerugian pihak lain dianggap sebagai hukuman yang benar. Mereka mencontohkan : tindakan pemerintah yang melakukan takeover suatu proyek setelah kontraktor / badan usaha menanamkan sejumlah besar uang. Namun karena terlambat menyelesaikan proyek ini diambil alih oleh pemerintah dengan argumen sebagai hukuman.

\section{Innovation Economics Theory (IE)}

Koschatzky (2017) menyatakan IE ini dapat diaplikasikan untuk menganalisis jenis distribusi dari proses inovasi, keterbukaan inovasi, penciptakan pengetahuan dan proses eksploitasi, peranan sumberdaya manusia dan orientasi pasar. Teori IE ini lebih berfokus pada peranan PPP sebagai suatu mode organisasi atas keterbukaan dan distribusi proses inovasi. Teori ini pada dasarnya ingin memperkaya PPP dari sekedar menyediakan atau membangun infrastruktur publik ke arah yang lebih inovatif baik kontribusi kepada riset-riset strategis maupun produk produk inovatif. Jadi teori IE ini lebih kepada pengadaan produk produk PPP yang komersial baik inovasi dalam bentuk teknologi, terkait proses, organisasional, budaya dan sosial.

\section{Economic Geography Theory (EG)}

Koschatzky (2017) teori EG mirip dengan teori IE yang menjelaskan tentang aspek inovasi, namun teori EG lebih berkonsentrasi pada aspek spasial dan kedekatan geografis. Pada dasarnya teori ini ingin mengatakan bahwa PPP haruslah berorientasi pada proses penciptaan inovasi dan harus mempertimbangkan aspek spasial dan kedekatan geografis proyek PPP dengan pihak terdampak (fokus pada aspek distribusi). Distribusi proses inovasi tergantung pada pengaruh dari bermacam macam faktor yaitu :model ketersalinghubungan antar agent (basis pengetahuan dan spesialisasi), dinamika dalam model distribusi dari agen (perubahan dalam mode distribusi) dan skala level inovasi (langkah langkah tambahan untuk perubahan fundamental).

\section{METODE PENELITIAN}

Disain penelitian yang digunakan pada tulisan ini bersifat deskriptif teoritis. Peneliti menggunakan logika berbasis fakta empiris untuk mengidentifikasi dan merumuskan proposisi terkait dengan fokus tulisan ini. Tehnik pengumpulan data yang digunakan adalah dokumentasi.

\section{Konsep Dasar KPBU atau PPP}

\section{HASIL DAN PEMBAHASAN}

Menurut Perpres 38 / 2015 Pasal 1 (6) Kerjasama Pemerintah dan Badan Usaha yang selanjutnya disebut sebagai KPBU adalah kerjasama antara pemerintah dan Badan Usaha dalam Penyediaan Infrastruktur untuk kepentingan umum dengan mengacu pada spesifikasi yang telah ditetapkan sebelumnya oleh Menteri/Kepala Lembaga/Kepala Daerah/Badan Usaha Milik Negara/Badan Usaha Milik Daerah, yang sebagian atau seluruhnya menggunakan sumber daya Badan Usaha dengan memperhatikan pembagian risiko diantara para pihak. Menurut Perpres 38 / 2015 Pasal 3, KPBU dilakukan dengan tujuan untuk: a. Mencukupi kebutuhan pendanaan secara berkelanjutan dalam Penyediaan Infrastruktur melalui pengerahan dana swasta; b. Mewujudkan Penyediaan Infrastruktur yang berkualitas, efektif, efisien, tepat sasaran, dan tepat waktu; c. Menciptakan iklim investasi yang mendorong keikutsertaan Badan Usaha dalam Penyediaan Infrastruktur berdasarkan prinsip usaha secara sehat; d. Mendorong digunakannya prinsip pengguna membayar pelayanan yang diterima, atau dalam hal tertentu mempertimbangkan kemampuan membayar pengguna; dan/atau e. Memberikan kepastian pengembalian investasi Badan Usaha dalam Penyediaan Infrastruktur melalui mekanisme pembayaran secara berkala oleh pemerintah kepada Badan Usaha.

Menurut Perpres 38 / 2015, Pasal 4, KPBU dilakukan berdasarkan prinsip: a. Kemitraan, yakni kerjasama antara pemerintah dengan Badan Usaha dilakukan berdasarkan ketentuan peraturan perundang-undangan dan persyaratan yang mempertimbangkan kebutuhan kedua belah pihak; b. Kemanfaatan, yakni Penyediaan Infrastruktur yang dilakukan oleh pemerintah dengan Badan Usaha untuk memberikan manfaat sosial dan ekonomi bagi masyarakat; c. Bersaing, yakni pengadaan mitra kerjasama Badan Usaha dilakukan melalui tahapan pemilihan yang adil, terbuka, an transparan, serta memperhatikan prinsip persaingan usaha yang sehat; d. Pengendalian dan 
pengelolaan risiko, yakni kerja sama Penyediaan Infrastruktur dilakukan dengan penilaian risiko, pengembangan strategi pengelolaan, dan mitigasi terhadap risiko; e. Efektif, yakni kerja sama Penyediaan Infrastruktur mampu mempercepat pembangunan sekaligus meningkatkan kualitas pelayanan pengelolaan dan pemeliharaan infrastruktur; dan f. Efisien, yakni kerja sama Penyediaan Infrastruktur mencukupi kebutuhan pendanaan secara berkelanjutan dalam Penyediaan Infrastruktur melalui dukungan dana swasta.

Menurut Maskin \& Tirole (2008) dalam Nsasira et al, (2013), tidak ada defenisi universal dari PPP. Tidak adanya defenisi tunggal atau absolut dari PPP karena lingkup PPP yang sangat luas. Perbedaan lingkup PPP ini dapat berupa ; Pertama, dari aspek hakikat dan bentuk kerjasama / partnership. Dari hakikat partnership, bisakah terjadi partnership yang efisien dan efektif jika kedua member (pemerintah dan private) memiliki perbedaan fungsi yang fundamental, jika pemerintah berbasis pada non profit sedangkan swasta berbasis pada orientasi profit. Pemerintah berorientasi pada barang publik sedangkan swasta pada barang private, yang karakteristik produk ini, baik sisi penciptaan dan delivery kepada pengguna akhir berbeda. Apakah bisa terjadi kolaborasi yang sanggup menghasilkan produk yang benar benar efisien baik dari sisi harga perolehan maupun optimalisasi manfaat atau fungsi produk akhir yang dikoloborasikan?

Ke dua, aspek dimensi waktu. PPP bisa berjangka waktu panjang, bisa 5, 10 tahun atau lebih. Ke tiga, lingkup pekerjaan. Pekerjaan dalam PPP bisa hanya sekedar kolaborasi dalam membangun atau sampai mengoperasikan dan memelihara. Ke empat, aspek pembiayaan. Pembiayaan dalam PPP bisa $100 \%$ dari pemerintah, atau sebagian dari swasta atau inisiatif swasta. Ke lima, risk sharing. Apakah resiko ditanggung pemerintah, sebagian ditanggung swasta atau seluruhnya ditanggung swasta. Kemudian jenis resiko yang ditanggung juga sangat bervariasi mulai dari konstruksi sampai resiko pemeliharaan dan bahkan resiko yang disebabkan oleh alam (force mayor). Ke enam, jenis produk yang dihasilkan. PPP bisa barang publik murni, quasi barang publik ataupun barang / produk komersial. Luasnya cakupan PPP ini yang menyebabkan tidak adanya defenisi tunggal yang cukup memuaskan dalam membatasi defenisi PPP ini.

Namun setidaknya ada beberapa defenisi yang dapat dijadikan acuan atas PPP ini yaitu : pertama, menurut Liu and hiraku (2009) bahwa model PPP adalah suatu bentuk kolaborasi antara sektor publik (pemerintah) dan swasta dengan tujuan untuk menyediakan jasa publik yang secara tradisional disediakan oleh sektor publik. Ke dua, menurut Koschatzky (2017) bahwa PPP sebagai suatu aktivitas jasa publik dan atau suatu aktivitas ekonomi swasta, dengan joint pembiayaan dan operasi oleh sektor publik dan industri berdasarkan suatu kontrak yang mengatur pembiayaan dan operasi tersebut. Ke tiga, menurut Akhmetshina et al (2017), PPP adalah suatu kelembagaan dan suatu aliansi organisasi dari otoritas pemerintah dan bisnis swasta yang bertujuan untuk merealisasikan proyek proyek penting secara sosial, dengan cakupan aktivitas : dari pengembangan sektor sektor ekomomi yang penting secara strategis sampai pada penyediaan jasa publik diseluruh negeri atau wilayah.

Ke empat, menurut Carbonara et al (2013), PPP adalah kolaborasi antara pemerintah dengan perusahaan swasta untuk membantu menyediakan jasa dan infrastruktur yang secara tradisional disediakan oleh sektor publik. Mereka juga menyatakan bahwa PPP merupakan kesepakatan dimana sektor publik masuk dalam kesepakatan kontrak jangka panjang dengan entitas sektor swasta untuk membangun atau mengelola fasilitas infrastruktur sektor publik. Pembangunan atau pengelolaan oleh pihak swasta ini mengatasnamakan sektor publik (pemerintah). Ke lima, menurut Qizilbash (2011), PPP adalah kerjasama antara sektor publik dan private atau LSM, untuk mengembangkan cara baru dalam memproduksi dan menyalurkan jasa publik, berbagi resiko dan imbalan, dimana semua pihak (publik, private dan masyarakat) mendapatkan benefit dari transkasi ini. Ke enam, Marthur (2014) mengutip defenisi PPP dari pemerintah India (departemen urusan ekonomi, kementerian keuangan) dan Asian Development Bank menyatakan PPP berarti perjanjian antara suatu pemerintah atau entitas berdasarkan undang undang atau entitas yang dimiliki pemerintah di satu pihak dan sektor swasta dipihak lain untuk menyediakan asset publik dan atau jasa terkait dengan manfaat publik, melalui investasi dan manajemen yang dikerjakan oleh entitas sektor publik untuk periode waktu tertentu dimana terdapat bagi resiko dengan sektor swasta dan sektor swasta akan menerima pembayaran terkait kinerjanya dengan standart yang spesifik, ditentukan diawal dan kinerja yang dapat diukur. Ke Tujuh, menurut Priya M.Sathana and P. Jesintha (2011) bahwa PPP merupakan kesepakatan antara pemerintah dan sektor publik dalam menyediakan jasa publik. Atau mendeskripsikan tentang suatu kerjasama antara pemerintah dengan bisnis swasta yang dibiayai dan dioperasikan melalui kerjasama / persekutuan antara pemerintah dengan satu atau lebih perusahaan sektor publik. 


\section{Karakteristik Dasar PPP}

Nsasira et al, (2013) mengatakan bahwa PPP memiliki beberapa ciri yaitu : (1) kerjasama jangka panjang bukan kolaborasi jangka pendek. (2) menekankan risk-sharing (bagi resiko) sebagai komponen vital. Kedua belah pihak akan menanggung bagian dari resiko yang timbul dari kerjasama tersebut. (3) para pihak bersama sama memproduksi sesuatu (barang atau jasa) dan secara implisit kedua belah pihak mendapatkan manfaat dari usaha bersama mereka. Mereka mengutip pendapat dari Maskin and Tirole (2008), karakteristik utama dari PPP adalah suatu contractual basis. Selanjutnya dikatakan bahwa dibanding dengan bentuk kerjasama tradisional lainnya, PPP memiliki karakteristik penting yaitu : (1) pola kepemilikan PPP berbeda dengan aliansi perusahaan karena salah satu sisi adalah organisasi yang dimiliki publik (pemerintah) sedangkan di sisi lain adalah organisasi yang dimiliki swasta. (2) Hasil atau output dari jenis kerjasama ini adalah produk atau jasa publik (atau setidaknya quasi-public). Hal ini berbeda dengan output perusahaan (private). (3) PPP biasanya bersifat kontrak jangka panjang dan tetap berpengaruh pada partner untuk waktu yang lama.

Karakteristik PPP yang lain dari Priya and Jesintha (2011), yang lebih menekankan pada tujuan PPP, yaitu mentargetkan aspek pembiayaan, mendisain, mengimplentasikan dan mengoperasikan fasilitas infrastruktur dan jasa dalam suatu negara. Menurut mereka PPP membatu mencapai pertumbuhan yang tinggi dan equity dalam suatu basis berkelanjutan. Pendapat yang mirip juga dari Iossa and Martimort (2009) yang menyatakan supplier atau pemenang kontrak akan mengambil tanggungjawab untuk membangun infrastruktur, membiayai investasi dan memelihara fasilitas ini. Karakteristik PPP yang lain diutarakan oleh Iossa and Martimort (2009) yaitu : (1) paket pekerjaan (suatu pekerjaan PPP terdiri dari rangkaian pekerjaan dari disain, membangun, membiayai dan mengoperasikan proyek yang dikontrakkan. Perusahaan biasanya bersifat perusahaan konsorsium yang bisa terdiri dari perusahaan konstruksi dan perusahaan manajemen fasilitas. Perusahaan bertanggungjawab pada semua aspek produk yang akan dihasilkan ) (2) transfer resiko ( kontrak PPP meliputi transfer resiko dan tanggungjawab pemerintah kepada kontraktor. Memang pemerintah yang menentukan jenis jasa apa dan bagaimana standart dasarnya, namun kemudian menyerahkan kepada konsorsium dengan hak kontrol dan tanggungjawabnya untuk membuat jasa sesuai dengan standart khususnya yang dibuat pemerintah. Jadi pada dasarnya, resiko disain, konstruksi dan operasional ditransfer ke private) (3) kontrak jangka panjang ( kontrak PPP minimal 20 sampai 35 tahun).

Liu and hiraku (2009) mengutip pendapat Teisman and Klijn (2002) yang menekankan bahwa skema PPP lebih didasari pada kerangka pembuatan keputusan bersama ketimbang sebagai hubungan prinsipal-agent. Pada konteks ini, masalah dalam PPP akan diidentifikasi dan dicarikan solusi oleh kedua belah pihak. Jadi prinsip dasar dari PPP adalah kerjsama atau kolaborasi dan saling mendukung antar partisipan, sharing sumberdaya, resiko, tanggungjawab dan imbalan antar kedua pihak yang terlibat. Nsasira et al, (2013), menambahkan bahwa delivery jasa dan pembuatan kebijakan dalam PPP telah menyebabkan pergeseran dari kebijakan "top-down" ke arah negoisasi dan efektif delivery. Di dalam PPP juga terdapat insentif kepada pihak swasta karena melakukan delivery jasa karena mereka melakukan peningkatan pada level efisiensi dan efektivitas. Peningkatan ini harus dilakukan karena terkait dengan gain atau manfaat (meningkatkan profit dan return), yang terkait dengan delivery jasa pada pemerintah.

Menurut Mathur (2014), karakteristik yang melekat dalam PPP adalah : (1) peranan pemerintah bisa sebagai fasilitator dan enabler dengan mengasumsikan resiko sosial, lingkungan dan politik. Sedangkan peranan pihak swasta adalah pendana, pembangun dan operator jasa atau fasilitas dengan mengasumsikan resiko kontruksi dan komersial. (2) pemerintah tetap melakukan perhitungan antar kualitas jasa, kepastian harga dan efektivitas biaya (value for money) dari perkongsian atau partnership. (3) proses PPP mencakup penilaian skala penuh resiko ketika pihak swasta mengasumsikan adanya resiko non kinerja dari aset dan saat merealisasikan return ketika asset dikerjakan. (4) PPP akan mendapatkan gain yang efisien dan meningkatkan dampak atas investasi. Untuk mencapai hal tersebut maka perlu cepat diimplementasikan, mengurangi siklus hidup biaya dan alokasi resiko yang optimal. Iossa and Martimort (2009), lebih menekankan pada bagaimana PPP itu optimal sebagai karakteristik dasarnya. Menurutnya PPP seharusnya memberikan dampak eksternalitas positip pada semua tahap PPP, karena jika positip maka akan meningkatkan insentif dari proyek PPP, mendapatkan transfer resiko yang sesuai kualitas terbaik hasil (yield) dan mendapatkan serta merealisasikan proyek proyek yang murah. Jadi pada dasarnya PPP harus menciptakan benefit terbaik. Hal ini bisa tercapai ketika infrastruktur berkualitas terbaik dapat menurunkan biaya 
pada tahapan operasional (termasuk biaya pemeliharaan), ketika kualitas infrastruktur memberikan dampak terbesar pada kualitas pelayanan publik

\section{Jenis Jenis Infrastruktur dalam KPBU di Indonesia}

Menurut Perpres 38 / 2015 Pasal 5 : (1) Infrastruktur yang dapat dikerjasamakan berdasarkan Peraturan Presiden ini adalah infrastruktur ekonomi dan infrastruktur sosial. (2) Jenis Infrastruktur ekonomi dan infrastruktur sosial sebagaimana dimaksud pada ayat (1) mencakup: a. infrastruktur transportasi; b. infrastruktur jalan; c. infrastruktur sumber daya air dan irigasi d. infrastruktur air minum; e. infrastruktur sistem pengelolaan air limbah terpusat; f. infrastruktur sistem pengelolaan air limbah setempat; g. infrastruktur sistem pengelolaan persampahan; h. infrastruktur telekomunikasi dan informatika; i. infrastruktur ketenagalistrikan; j. infrastruktur minyak dan gas bumi dan energi terbarukan; k. infrastruktur konservasi energi; 1 . infrastruktur fasilitas perkotaan; m. infrastruktur fasilitas pendidikan; $n$. infrastruktur fasilitas sarana dan prasarana olahraga, serta kesenian; o. infrastruktur kawasan; p. infrastruktur pariwisata; q. infrastruktur kesehatan; r. infrastruktur lembaga pemasyarakatan; dan s. infrastruktur perumahan rakyat.

Untuk jenis infrastruktur yang bisa di KPBU kan, lebih detail dapat di lihat pada Permen PPN no 4 / 2015 , Pasal 3, Infrastruktur yang dapat dikerjasamakan berdasarkan Panduan Umum ini mencakup: a. infrastruktur transportasi, antara lain: (1. penyediaan dan/atau pengelolaan fasilitas dan/atau pelayanan jasa kebandarudaraan, termasuk fasilitas pendukung seperti terminal penumpang dan kargo). 2. penyediaan dan/atau pengelolaan fasilitas dan/atau pelayanan jasa kepelabuhanan; 3. sarana dan/atau prasarana perkeretaapian; 4. sarana dan prasarana angkutan massal perkotaan dan lalu lintas; dan/atau 5. sarana dan prasarana penyeberangan laut, sungai, dan/atau danau). b. infrastruktur jalan, antara lain: (1. jalan arteri, jalan kolektor dan jalan lokal; 2. jalan tol; dan/atau 3. jembatan tol.). c. infrastruktur sumber daya air dan irigasi, antara lain: (1. saluran pembawa air baku; dan/atau 2. jaringan irigasi dan prasarana penampung air beserta bangunan pelengkapnya, antara lain waduk, bendungan, dan bendung). d. infrastruktur air minum, antara lain: (1. unit air baku; 2. unit produksi; dan/atau 3. unit distribusi). e. infrastruktur sistem pengelolaan air limbah terpusat, antara lain: (1. unit pelayanan; 2. unit pengumpulan; 3. unit pengolahan; 4. unit pembuangan akhir; dan/atau 5. saluran pembuangan air, dan sanitasi). f. infrastruktur sistem pengelolaan air limbah setempat, antara lain: (1. unit pengolahan setempat; 2. unit pengangkutan; 3. unit pengolahan lumpur tinja; 4. unit pembuangan akhir; dan/atau 5. saluran pembuangan air, dan sanitasi). g. infrastruktur sistem pengelolaan persampahan, antara lain: (1. pengangkutan; 2. pengolahan; dan/atau 3. pemrosesan akhir sampah). h. infrastruktur telekomunikasi dan informatika, antara lain: (1. jaringan telekomunikasi; 2. infrastruktur e-government; dan/atau 3. infrastruktur pasif seperti pipa saluran media transmisi kabel (ducting)). i. infrastruktur energi dan ketenagalistrikan, termasuk infrastruktur energi terbarukan, antara lain: ( 1. infrastruktur ketenagalistrikan, antara lain: a) pembangkit listrik; ) transmisi tenaga listrik; c) gardu induk; dan/atau d ) distribusi tenaga listrik). 2. infrastruktur minyak dan gas bumi, termasuk bioenergi, antara lain: (a) pengolahan; b) penyimpanan; c) pengangkutan; dan/atau d) distribusi. j. infrastruktur konservasi energi, antara lain: ( 1. penerangan jalan umum; dan/atau 2. efisiensi energi). k. infrastruktur ekonomi fasilitas perkotaan, antara lain: (1. saluran utilitas (tunnel); dan/atau 2. pasar umum.). 1. infrastruktur kawasan, antara lain: ( 1. kawasan pengembangan ilmu pengetahuan, teknologi dan inovasi termasuk pembangunan science and techno park; dan/atau 2. kawasan industri. m. infrastruktur pariwisata, antara lain pusat informasi pariwisata (tourism information center). n. infrastruktur fasilitas pendidikan, penelitian dan pengembangan, antara lain: (1. sarana pembelajaran; 2. laboratorium; 3. pusat pelatihan; 4. pusat penelitian/pusat kajian; 5. sarana dan prasarana penelitian dan pengembangan; 6. inkubator bisnis; 7. galeri pembelajaran; 8. ruang praktik siswa; 9. perpustakaan; dan/atau 10. fasilitas pendukung pembelajaran dan pelatihan.) o. infrastruktur fasilitas sarana olahraga, kesenian dan budaya, antara lain: (1. gedung/stadion olahraga; dan/atau 2. gedung kesenian dan budaya). p. infrastruktur kesehatan, antara lain: (1. rumah sakit, seperti bangunan rumah sakit, prasarana rumah sakit, dan peralatan medis; 2 . fasilitas pelayanan kesehatan dasar, seperti bangunan, prasarana, dan peralatan medis baik untuk puskesmas maupun klinik; dan/atau 3. laboratorium kesehatan, seperti bangunan laboratorium kesehatan, prasarana laboratorium kesehatan dan peralatan laboratorium. q. infrastruktur pemasyarakatan, antara lain: (1. lembaga pemasyarakatan; 2. balai pemasyarakatan; 3. rumah tahanan negara; 4. rumah penyimpanan benda sitaan dan barang rampasan negara; 5 . lembaga penempatan anak sementara; 6. lembaga pembinaan khusus anak; dan/atau 7. rumah sakit 
pemasyarakatan.) r. infrastruktur perumahan rakyat, antara lain: (1. perumahan rakyat untuk golongan rendah; dan/atau 2. rumah susun sederhana sewa)

Menurut Perpres 38 / 2015, Pasal 7, (1) Dalam hal KPBU merupakan gabungan dari 2 (dua) atau lebih jenis Infrastruktur, Menteri/Kepala Lembaga/Kepala Daerah yang memiliki kewenangan terhadap sektor infrastruktur yang dikerjasamakan berdasarkan peraturan perundang-undangan, bertindak bersama-sama sebagai PJPK. (2) Menteri/Kepala Lembaga/Kepala Daerah yang memiliki kewenangan terhadap sektor Infrastruktur yang akan dikerjasamakan sebagaimana dimaksud pada ayat (1) menandatangani nota kesepahaman mengenai PJPK (3) Nota kesepahaman sebagaimana dimaksud pada ayat (2) paling kurang memuat: a. kesepakatan pihak yang menjadi koordinator PJPK; b. kesepakatan mengenai pembagian tugas dan anggaran dalam rangka penyiapan, transaksi, dan manajemen KPBU; dan c. jangka waktu pelaksanaan KPBU. Juga menurut Permen PPN no 4 / 2015, Pasal 8, (1) KPBU dapat merupakan gabungan dari 2 (dua) atau lebih jenis Infrastruktur. (2) Dalam hal gabungan dari 2 (dua) atau lebih jenis Infrastruktur sebagaimana dimaksud pada ayat (1) melibatkan lebih dari 1 (satu) PJPK, Menteri/Kepala Lembaga/Kepala Daerah yang memiliki kewenangan terhadap masing-masing sektor Infrastruktur yang akan dikerjasamakan, bertindak bersama-sama sebagai PJPK. (3) Menteri/Kepala Lembaga/Kepala Daerah yang memiliki kewenangan sebagaimana dimaksud pada ayat (2), menandatangani nota kesepahaman. (4) Nota kesepahaman sebagaimana dimaksud pada ayat (3) memuat sekurang-kurangnya: a. kesepakatan pihak yang menjadi koordinator PJPK; b. kesepakatan pembagian tugas dan tanggung jawab masing-masing PJPK, termasuk hak dan kewajiban masing masing PJPK dalam perjanjian KPBU; c. kesepakatan penganggaran dalam rangka tahap penyiapan dan tahap transaksi, termasuk manajemen KPBU; d. jangka waktu berlakunya nota kesepahaman; dan e. jangka waktu pelaksanaan KPBU.

\section{Bentuk KPBU atau PPP}

Mathur (2014), mengutip Asian Development Bank (2000) and World Bank 0(2004) menyatakan bahwa bentuk partenership yang banyak digunakan diseluruh dunia dapat diklasifikasikan sebagai berikut : (1) Service Contract and Management Contract (2) Turnkey contracts (3) Lease contract (4) Concession (5) Private Finance Initiative and Private ownership.

Service Contracts and Management contracts. Merupakan rencana kontraktual untuk mengelola atau memanajemen sebagian atau seluruh suatu proyek publik oleh perusahan swasta. Kontrak ini membolehkan keahlian sektor swasta untuk masuk dalam mendisain jasa dan mendeliverinya, kontrol operasi, manajemen tenaga kerja, pengadaan peralatan, tampa menanggung resiko komersial. Pemerintah tetap sebagai pemilik fasilitas dan peralatan. Swasta mendapatkan fee untuk memanajemeni dan mengoperasionalkan berbasis kinerja.

Turnkey Contracts. Kontraktor swasta diseleksi melalui proses penawaran. Kontraktor akan mendisain dan membangun suatiu fasilitas dengan fee atau total cost yang tetap, dimana terdapat kriteria kunci dalam memilih pemenang, resiko diasumsikan masuk dalam tahapan disain dan konstruksi. Kontrak ini biasanya jangka pendek dan investasi swasta kecil. (paling banyak digunakan, uang dari pemerintah, kontraktor hanya bangun saja). Misalnya : pembangkit listrik.

Affermage / Lease. Operator bertanggungjawab untuk mengoperasikan dan memelihara fasilitas infratsruktur (sudah dibangun sebelumnya) dan jasa. Operator tidak mengeluarkan investasi. Namun seringkali, model kontrak ini dikombinasikan dengan model lainnya seperti : model build-rehabilitate-operate-transfer. Pada kasus ini periode kontrak relatif lebih lama dan swasta membutuhkan investasi yang cukup signifikan. Pada kondisi ini, sangat biasa menggunakan bentuk affermage and a lease. Kedua bentuk ini hanya berbeda secara teknis saja. Kalau lease, operator menahan pendapatan yang diperoleh dari konsumen atau pengguna fasilitas dan melakukan pembayaran fee leasing dalam jumlah tertentu kepada otoritas pemberi kontrak (pemerintah). Namun untuk affermage, operator dan pemberi kontrak berbagi revenue dari konsumen atau pengguna. Untuk lahan yang digunakan dalam bentuk ini biasanya ditransfer setelah 15-30 tahun. Misalnya : proyek taman kota.

Concessions. Pada bentuk ini, pemerintah hak membuat dan memberikan bantuan (uang) kepada perusahan swasta untuk membangun dan mengoperasikan fasilitas dengan periode waktu tertentu / tetap. Pemilik proyek tetap pemerintah dan hak untuk mengsupply jasa tetap pada pemerintah. Dalam konsensi ini, pembayaran dapat ditempuh dengan dua cara : (a) pelaksana konsensi yang membayar kepada pemerintah karena hak konsensi (b) pemerintah membayar kepada pelaksana konsensi. Kedua pembayaran ini didasari pada kesepakatan kedua belah pihak dengan syarat-syarat khusus. Untuk mode pembayaran dari pemerintah ke pelaksana konsensi, pemerintah harus membuat 
proyek layak secara komersial atau menurunkan tingkat resiko komersial yang ditanggung oleh sektor swasta, biasanya dalam proyek proyek PPP yang sementara dikembangkan atau pasarnya yang belum teruji. Rentang waktu konsensi adalah 5-50 tahun.

Model kosensi, memiliki banyak varian atau turunan model yang digunakan yaitu : Pertama, Build Own Operate (BOO). Pemerintah memberikan hak untuk membiayai, mendisain, membangun, mengoperasikan dan memelihara kepada swasta. Swasta tidak disyaratkan untuk mentransfer fasilitas kepada pemerintah (misalmya : KEK). Kedua, Build Operate Transfer (BOT). swasta membangun dan mengoperasikan fasilitas publik untuk periode waktu yang signifikan (panjang). Namun setelah waktu habis maka fasilitas itu diberikan kepada pemerintah. Contoh : jalan. Ketiga, Build-Own-Operate-Transfer (BOOT). Pemerintah memberikan franchise kepada swasta untuk membiayai, mendisain, membangun dan mengoperasikan fasilitas untuk periode waktu tertentu. Pada periode waktu itu, fasilitas dimiliki penuh oleh swasta namun setelah habis periode akan diberikan kepada pemerintah. Misalnya : pelabuhan udara. Keempat, Design-Build-Operate (DBO). Adalah kontrak tunggal yang diberikan kapada swasta dalam mendisain, membangun dan mengoperasikan fasilitas publik, namun pemerintah tetap sebagai pemilik. Kelima, Build-Develop-Operate (BDO). Swasta membeli fasilitas publik, kemudian memperbaharui kembali (mengembangkan) dengan sumberdaya sendiri kemudian mengoperasikannya melalui kontrak dengan pemerintah. (misalnya : kebun binatang). Keenam, Build-Own-Lease-Transfer (BOLT). Pemerintah memberikan grant atas hak untuk membiayai dan membangun proyek dan kemudian di leased back kepada pemerintah dengan fee dan kesepakatan tertentu dengan swasta. Fasilitas ini tetap dioperasikan oleh pemerintah, namun diakhir periode akan diberikan kepada pemerintah. (misalnya : food court). Ketujuh, kesepakatan kontraktual dimana proyek yang dibangun (infrstruktur baru) oleh swasta diintegrasikan dengan rencana yang memberikan swasta hak untuk mengembangkan dan menerima beberapa manfaat yang dihasilkan dari investasinya. Manfaat ini bisa nilai tinggi dari properti dan nilai sewa. Ketujuh, Rehabilitate Operate and Transfer (ROT). Kesepakatan kontraktual dimana suatu fasilitas eksisting (yang telah ada) diberikan kepada swasta untuk diperbaharui kembali, kemudian dioperasikan dan dipelihara selang periode tertentu sebagai suatu franchisee, dan pada akhir periode dikembalikan kepada pemerintah. (mis: gues house untuk kesehatan dan spa di India). Kedelapan, Design-Build-Operate $(D B O)$. Swasta mendisain dan membangun fasilitas serta mengoperasikannya dalam periode tertentu. Kesembilan, Design-Build-Finance-Operate/Maintain (DBFO, DBFM or DBFO/M). Swasta yang mendisain, membangun, membiayai, mengoperasikan dan atau memelihara fasilitas baru dalam lease jangka panjang. Dan pada akhir periode akan dikembalikan ke pemerintah. Contoh: Up gradation of Nehru Zoological Park, Bird Park at Kothaguda, Development of Intercity Bus Terminal at Miyapur, Hyderabad

Private Finance Initiative (PFI). Pada mode ini, swasta bertanggungjawab penuh untuk disain, konstruksi, operasi sampai pada pemeliharaan. Dalam beberapa kasus, pemerintah memberikan hak kepemilikan asset kepada swasta. Namun dalam jangka panjang, pemerintah akan membeli infrastruktur tersebut dari swasta. Juga pemerintah mentrasfer resiko dan biaya disain dan kontruksi pada swasta.

\section{Faktor Faktor Sukses Implementasi KPBU \\ Kemampuan Komprehensip KPBU Pemerintah}

Menurut Estache (2014) melihat dari sisi pemerintah atau otoritas publik. Ia mengatakan bahwa pemerintah harus meningkatkan kemampuan mereka yang meliputi ; (1) kemampuan mengidentifikasi proyek yang akan dibiayai oleh PPP (misalnya: proyek yang menciptakan nilai sosial yang tinggi) (2) kemampuan untuk menetapkan karakteristik jasa (3) kemampuan untuk menyepakati imbalan (4) kemampuan bekerja dengan kontrak yang detail (5) kemampuan berinvestasi dalam penguatan kontrak. Kemampuan pemerintah merupakan faktor yang sangat menentukan dalam kesuksesan implementasi KPBU. Semakin tinggi, detail dan kompleks kemampuan pemerintah atas karakteristik dan pembiayaan KPBU maka semakin sukses proyek proyek KPBU yang ditanganinya. Berdasarkan logika ini maka proposisi dapat disusun sebagai berikut :

Kurangnya kemampuan pemerintah dalam memahami karakteristik dan implementasi proyek KPBU jangka panjang akan menyebabkan proyek tersendat atau terhenti di tengah jalan. Jika ini terjadi maka akan timbul kerugian di kedua belah pihak (apalagi jika kedua belah pihak telah menanamkan investasi dalam jumlah besar). Kurangnya kemampuan pemerintah ini juga berpengaruh pada tingginya tingkat resiko yang akan dihadapi pihak swasta, resiko yang tinggi akan dikompensasikan dengan return atau tingkat pengembalian investasi yang diharapkan yang tinggi oleh pihak swasta. Jika hal ini terjadi maka kerugian bukan hanya dialami oleh para pihak 
yang terikat pada kontrak KPBU, juga pada masyarakat yang akan tertunda dalam mengkonsumsi jasa atau ouput dari proyek KPBU ini.

Proposisi 1 : Kemampuan pemerintah dalam mengenal karakteristik dan implementasi proyek KPBU akan berkorelasi positip dengan kesuksesan implementasi KPBU. Kemampuan pemerintah ini berupa: kemampuannya untuk mengidentifikasi proyek proyek KPBU yang bernilai, kemampuan untuk membuat perencanaan yang detail terhadap proyek proyek KPBU, kemampuan untuk bekerjasama dengan pihak swasta dalam hal pembangunan, kemampuan untuk membuat kontrak KPBU yang konsisten dan memnguntungkan para pihak, dan kemampuan keuangan untuk melakukan investasi dengan para pihak.

\section{Kelembagaan Dalam KPBU}

Aspek kelembagaan KPBU juga sangat penting dalam kesuksesan implementasi KPBU. Menurut Akhmetshina et al (2017), PPP adalah suatu kelembagaan dan suatu aliansi organisasi dari otoritas pemerintah dan bisnis swasta yang bertujuan untuk merealisasikan proyek proyek penting secara sosial, dengan cakupan aktivitas : dari pengembangan sektor sektor ekomomi yang penting secara strategis sampai pada penyediaan jasa publik diseluruh negeri atau wilayah. Menurut Qizilbash (2011) bahwa aspek kelembagaan merupakan faktor sukses dari KPBU. Aspek ini terkait dengan konsep seperti : kerangka delegasi pengelolaan, manajemen asset, manajemen kontrak, isu isu operasional dan tubuh regulasi yang terkait dengan peran pemerintah pusat atau daerah dalam PPP. Carbonara et al (2013) dalam artikelnya menulis bahwa ada tiga level atau lapis analisis dalam PPP yaitu : (1) level atau lapis country (negara atau nasional) (2) level atau lapis sektor (3) level atau lapis proyek. Pada level atau lapis negara atau nasional, penelitian bisa difokuskan pada dimensi kelembagaan, hukum, ekonomi dan keuangan dari PPP. Dari sisi kelembagaan dapat dianalisis tentang ada atau tidaknya kelembagaan yang khusus yang mendukung pengembangan PPP. Dari sisi administratif kelembagaan dan hukum dapat dianalisis tentang apakah kedua aspek ini mampu mempromosikan PPP (PPP task-forces, PPP legislation, and specific government initiatives to foster $P P P s)$ dan memfasilitasi delivery proyek proyek yang kompleks melalui sentralisasi atau desentralisasi kebijakan terkait PPP (misalnya : persetujuan perencanaan PPP di level lebih bawah, misalnya : kepala daerah) dan implementasi PPP pada level negara. Juga di dalam Permen PPN no 4 / 2015, Pasal 23, ayat 1, menyatakan Penyiapan kajian KPBU memuat kegiatan Prastudi Kelayakan, yang terdiri dari: a. penyiapan kajian awal Prastudi Kelayakan, terdiri dari: kajian hukum dan kelembagaan.

Menurut Perpres 38 / 2015 dan Permen PPN no 4 / 2015, terdapat tiga lembaga utama yang terkait dengan KPBU yaitu Pertama, PJPK (menteri /Kepala Lembaga / Kepala Daerah), dengan tugas utama adalah memberikan dukungan pemerintah dan Memberikan jaminan pemerintah (penjaminan infrastruktur). Kedua, Menteri Keuangan, dengan tugas utama adalah merumuskan bentuk dan cara pemberian dukungan kelayakan dan merumuskan Pengendalian dan pengelolaan risiko atas Jaminan Pemerintah. Ketiga, Badan Usaha Penjaminan Infrastruktur, dengan tugas utama adalah merumuskan Jaminan Pemerintah. Menurut saya, untuk mengkoordinasikan atau menghubungkan antar lembaga ini maka diperlukan suatu lembaga sejenis lembaga pengelolaan KBPU satu atap. Jadi para pihak yang ingin masuk dalam proyek KPBU hanya berhadapan dengan satu lembaga saja. Fungsi lembaga ini adalah mengelola (perencanan, pengorganisasian, pelaksanaan dan pengawasan) proyek proyek KPBU. Ketersediaan lembaga yang bersifat PTSP / single windows yang profesional dan fleksibel akan menjadi faktor sukses implementasi KPBU.

Proposisi 2: Ketersediaan lembaga khusus yang menangani KPBU, yang bekerja dalam regulasi yang fleksibel dan manajemen profesional akan berkorelasi positip dengan kesuksesan implementasi $K P B U$.

\section{Imbalan Bagi Pihak Swasta Yang Menarik}

Apa yang dapat dilakukan oleh pemerintah dan swasta dalam mengkompensasi resiko dalam proyek PPP ? dari sisi pemerintah, pemerintah dapat menaikkan pajak atau menurunkan tarif penggunaan jasa sebagai cara membayar terhadap kewajibannya. Misalnya; pemerintah dapat meningkatkan tarif jalan tol kepada pengguna jalan tol (proyek PPP) jika memang resiko kerugian tinggi. Dari sisi pihak swasta, akan memunggut tarif premium kepada pemerintah atau pun kepada masyarakat yang menggunakan jasa tersebut. 
Kondisi ini bisa terjadi jika alokasi resiko kepada pihak swasta tidak diperhitungkan dengan matang. Alokasi resiko yang tidak dikalkulasi dengan matang akan berdampak pada dua hal yaitu kelebihan investasi dari yang direncanakan dan peningkatan tarif sebagai kompensasi biaya modal yang tinggi kepada pihak swasta. Memang pada kondisi ini, strategi satu satunya adalah melakukan negoisasi ulang antara pemerintah dan swasta. Negoisasi ulang proyek PPP akan menimbulkan biaya dan memakan waktu. Juga bisa timbul masalah keagenan jika salah satu pihak tidak memiliki informasi sebaik informasi dari pihak lainnya. Jika pemerintah kurang memiliki informasi yang sempurna atas kondisi ini maka pihak swasta dapat berperilaku oportunistik dan berpotensi merugikan pemerintah atau masyarakat yang mengkonsumsi layanan proyek PPP tersebut

Bagi pihak swasta, imbalan atau reward yang bisa diperoleh dari proyek proyek KPBU sangat penting. Imbalan merupakan hasil yang bersumber baik dari membangun atau berinvestasi dari proyek KPBU. Menurut Iossa and Martimort (2009) bahwa terkait prosedur pemberian imbalan / keuntungan adalah hal yang dapat dijadikan pertimbangan agar PPP sukses. Demikian juga pendapat dari Qizilbash (2011), PPP adalah kerjasama antara sektor publik dan private atau LSM, untuk mengembangkan cara baru dalam memproduksi dan menyalurkan jasa publik, berbagi resiko dan imbalan, dimana semua pihak (publik, private dan masyarakat) mendapatkan benefit dari transkasi ini. Menurut Liu and hiraku (2009) mengutip pendapat Teisman and Klijn (2002) yang menekankan bahwa skema PPP lebih didasari pada kerangkan pembuatan keputusan bersama ketimbang sebagai hubungan prinsipal-agent. Pada konteks ini, masalah dalam PPP akan diidentifikasi dan dicarikan solusi oleh kedua belah pihak. Jadi prinsip dasar dari PPP adalah kerjsama atau kolaborasi dan saling mendukung antar partisipan, sharing sumberdaya, resiko, tanggungjawab dan imbalan antar kedua pihak yang terlibat. Dan juga dari pendapat Estache (2014) melihat dari sisi pemerintah atau otoritas publik. Ia mengatakan bahwa pemerintah harus meningkatkan kemampuan mereka yang meliputi ; (1) kemampuan mengidentifikasi proyek yang akan dibiayai oleh PPP (misalnya: proyek yang menciptakan nilai sosial yang tinggi) (2) kemampuan untuk menetapkan karakteristik jasa (3) kemampuan untuk menyepakati imbalan. Untuk faktor faktor sukses PPP di China, sangat kompleks. Menurut Liu and hiraku (2009), tantangan PPP di China berupa Daya Tarik dan Imbalan. Pemerintah China enggan untuk membolehkan adanya profit dalam infrastruktur publik. Mereka yakin bahwa penduduk miskin tidak akan mampu membayar jasa jika infrastruktur publik dioperasikan oleh swasta. Untuk daya tarik tergantung apakah proyek PPP menawarkan benefit yang baik atau tidak pada swasta, karena swasta mencari laba dan pemerintah menjamin investor mendapatkan laba yang sesuai atau layak.

Imbalan atau keuntungan juga menjadi aspek resiko, menurut Mathur (2014) mengidentifikasi beberapa jenis resiko yang bisa timbul dalam proyek PPP yaitu ; (1) Resiko Politik. Resiko menyangkut (salah satunya) adalah kurangnya konsistensi dalam kriteria imbalan suatu proyek. Sedangkan menurut menurut Perpres 38 / 2015, Pasal 29, 3) Biaya penyiapan KPBU yang dapat dibebankan kepada Badan Usaha pemenang lelang meliputi: a. biaya penyiapan prastudi kelayakan; b. biaya transaksi; c. imbalan terhadap Badan Usaha dan lembaga/institusi/organisasi internasional pelaksana penyiapan yang dibayarkan berdasarkan keberhasilan transaksi KPBU (success fee); dan d. biaya lain yang sah.

Proposisi 3 : Ketersediaan imbalan atau return yang menarik atau valuable bagi swasta yang terlibat dalam proyek proyek KBPU berkorelasi dengan kesuksesan implementasi KPBU. Kemudahan prosedur pembayaran imbalan atau return dan konsistensinya di masa depan akan mengurangi resiko imbalan atau return, hal ini akan menghasilkan daya tarik tinggi dari swasta untuk berpartisipasi dalam proyek proyek KPBU.

\section{Kepastian Hukum}

Menurut Nsasira et al, (2013) yang mengutip Klijn and Teisman (2003) bahwa kesuksesan implementasi PPP tergantung pada tingkat besaran (salah satunya) adalah dukungan prosedur hukum. Pendapat lain dari Mathur (2014), yang lebih menekankan pada aspek resiko hukum. Ia menyatakan bahwa resiko hukum menyangkut kerangka hukum, penyelesaian perselisihan, pencaplokan dan nasionalisasi. Juga bisa terkait dengan masalah properti leasing, ketidakmampuan membayar hutang perusahaan induk, perubahan dalam hukum dan regulasi, pelanggaran dokumen keuangan, persetujuan pengembangan dan lain lain. Masalah hukum sebagai faktor sukses dalam PPP juga disampaikan oleh Carbonara et al (2013) yang menyatakan aspek hukum khususnya legalitas hukum atas status PPP dapat mempromosikan PPP. 
Aspek legalitas KPBU di Indonesia juga didukung oleh Perpres 38 / 2015, Pasal 32, (1) PJPK menyiapkan perjanjian KPBU. (2) Perjanjian KPBU paling kurang memuat ketentuan mengenai: a. lingkup pekerjaan; b. jangka waktu; c. Jaminan pelaksanaan; d. tarif dan mekanisme penyesuaiannya; e. hak dan kewajiban termasuk alokasi risiko; f. standar kinerja pelayanan; g. pengalihan saham sebelum KPBU beroperasi secara komersial; h. sanksi dalam hal para pihak tidak memenuhi ketentuan perjanjian; i. pemutusan atau pengakhiran perjanjian; j. status kepemilikan aset; k. mekanisme penyelesaian sengketa yang diatur secara berjenjang, yaitu musyawarah mufakat, mediasi, dan arbitrase/pengadilan; 1. mekanisme pengawasan kinerja Badan Usaha Pelaksana dalam melaksanakan pengadaan; $m$. mekanisme perubahan pekerjaan dan/atau layanan; n. mekanisme hak pengambilalihan oleh Pemerintah dan pemberi pinjaman; o. penggunaan dan kepemilikan aset infrastruktur dan/atau pengelolaannya kepada PJPK; p. pengembalian aset infrastruktur dan/atau pengelolaannya kepada PJPK; q. keadaan memaksa; r. pernyataan dan jaminan para pihak bahwa perjanjian KPBU sah dan mengikat para pihak dan telah sesuai dengan peraturan perundang-undangan; s. penggunaan bahasa dalam Perjanjian, yaitu Bahasa Indonesia atau apabila diperlukan dapat dibuat dalam Bahasa Indonesia dan Bahasa Inggris (sebagai terjemahan resmi/official translation), serta menggunakan Bahasa Indonesia dalam penyelesaian perselisihan di wilayah hukum Indonesia; dan t. hukum yang berlaku, yaitu hukum Indonesia. Juga pada aspek pra studi kelayakan, memang disyaratkan kajian hukum (Perpres 38 / 2015, pasal 7 DancPermen PPN no 4 / 2015, pasal 8.

Proposisi 4 : Kesuksesan implementasi KPBU juga dipengaruhi oleh kepastian dan jaminan hukum. Aspek hukum akan mengurangi resiko dikemudian hari jika terjadi konflik antar pihak yang menandatangani kontrak KPBU. Semakin detail kontrak atau perjanjian hukum KPBU maka semakin baik kontrak atau perjanjian hukum KPBU. Kondisi ini akan menciptakan rasa percaya antar pihak sehingga mereka akan berfokus pada operasi atau kegiatan kegiatan untuk mengsukseskan implementasi proyek proyek KPBU tersebut.

\section{Perilaku Oportunistik}

Perilaku opportunistik atau perilaku untuk mencari keuntungan sangat merugikan dalam kontrak KPBU. Perilaku oportunistik akan memberikan dampak negatif terhadap kelangsungan dan kualitas proyek yang ditangani. Perilaku oportunistik bisa dilakukan oleh pemerintah maupun pihak swasta dalam suatu kontrak KPBU. Qu and Loosemore (2013) mencontohkan tindakan pemerintah yang melakukan takeover suatu proyek setelah kontraktor / badan usaha menanamkan sejumlah besar uang. Namun karena terlambat menyelesaikan proyek ini diambil alih oleh pemerintah dengan argumen sebagai hukuman. Dalam kasus ini, kerugian pihak lain dianggap sebagai hukuman yang benar. Mereka lebih detail menjelaskan perilaku opoortunistik ini dalam teori keagenan, misalnya dalam konteks Asset specificity. Elemen kekhususan asset ini, pada dasarnya ingin menyatakan bahwa transaksi yang bersifat "durable transaction-specific investments", tidak mungkin digunakan untuk tujuan lain tanpa adanya kerugian financial antar pihak dalam PPP. Sifat asset ini menjadi hambatan para pihak untuk keluar dari suatu hubungan kerjasama. Semakin besar asset ini semakin rugi para pihak jika bersifat opportunistik. Artinya ada biaya yang lebih besar yang ditanggung oleh para pihak jika tidak melanjutkan kontrak ketimbang melanjutkannya. Dan jika salah satu parner atau pihak mengetahui pihak lain berkomitment meneruskan hubungan ini tampa adanya peningkatan biaya maka akan ada peluang untuk berperilaku opportunistik.

$\mathrm{Qu}$ and Loosemore (2013) menyatakan agency theory (AT) bertolak belakang dengan TCET (transaction cost economic theory). Kalau pada TCET kontrak belum komplit maka pada AT kontrak diasumsikan telah komplit. AT mengasumsikan bahwa baik agent dan prinsipal bersifat rasional dan memiliki kepentingan pribadi (selfinterested). Untuk kesamaan antara AT dan TCET adalah aspek rasional terbatas namun pada AT rasional terbatas ini atas ketidaksimetrisan informasi (information asymmetry) antar pihak. Ketidaksimetrisan informasi (salah satu pihak mengetahui sedangkan pihak lain tidak atau pihak lain memiliki informasi yang superior sedangkan yang lain tidak) akan menciptakan perilaku oportunis. Juga dalam AT menyebabkan adverse selection atau moral hazard. Ketika salah satu partner memiliki motif untuk menipu dan partner tersebut memiliki keunggulan informasi relatif terhadap pihak lain dalam suatu hubungan maka pihak tersebut memiliki peluang yang baik untuk melakukan apa yang ia inginkan. 
Proposisi 5: Kesuksesan proyek KPBU secara jangka panjang akan ditentukan oleh mampu atau tidaknya kontrak KPBU dalam meminimalisasi perilaku opportunistik para pihak yang terlibat didalamnya.

Proposisi 5a : Perilaku oportunistik dapat disebabkan karena adanya assymetric information, tidak sempurnanya kontrol, kurangnya komitment, self interest seeking dan spesifikasi asset. Assymetric information dapat menyebabkan terjadinya adverse selection atau moral hazard dalam implementasi kontrak KPBU.

Proposisi 5b : Semakin tinggi ketidakmampuan para pihak dalam mengontrol satu dengan yang lainnya maka semakin besar kemungkinan terjadinya perilaku opportunistik dari para pihak dalam $P P P$

Proposisi 5c : Aspek hukuman atau pinalti yang signifikan dan detailnya kontrak KPBU dapat menjadi faktor penghambat para pihak untuk berperilaku opportunistik. Hukuman atau pinalti yang signifikan berarti adanya biaya yang lebih besar yang ditanggung oleh para pihak jika tidak melanjutkan kontrak ketimbang melanjutkannya.

Proposisi 5d: Bentuk bentuk perilaku opportunistik yang bisa terjadi dalam kontrak KPBU dapat berupa : Underbidding, Free riding, Sitting on the job, Poor quality of performance, Hostile takeover, Power misuse dan social surplus capture. (diadopsi dari Qu Y and Loosemore M, 2013) Proposisi 5e: Pada tahap pre-tendering (perilaku opportunistik yang dapat terjadi adalah : free riding (dari pemerintah) dan power mis use(dari pemerintah). Pada tahap bidding (perilaku opportunistik yang dapat terjadi adalah : free riding (pemerintah), underbidding (swasta). Pada tahap building (perilaku opportunistik yang dapat terjadi adalah sitting on the job (swasta), poor performance (swasta), power mis use (pemerintah), social surplus capture (pemerintah atau swasta). Pada tahap operasi (perilaku opportunistik yang dapat terjadi adalah hostile takeover (pemerintah) dan social surplus capture (pemerintah atau swasta). (diadopsi dari $\mathrm{Qu} \mathrm{Y}$ and Loosemore M, 2013)

Proposisi 5f : Kebanyakan terjadinya resiko dalam PPP berada diantara masa atau periode penawaran dan pembangunan sedangkan terkecil ada pada tahap pra tender. Self interest seeking adalah faktor atau elemen yang dominan mempengaruhi perilaku oportunistik dalam PPP, dan yang terendah adalah alasan ketidakpastian lingkungan. Aspek superordination adalah aspek yang paling dominan digunakan sebagai bentuk perilaku oportunistik dalam PPP.(diadopsi dari $\mathrm{Qu} \mathrm{Y}$ and Loosemore M, 2013)

\section{PENUTUP}

Dari hasil bahasan diatas dapat disimpulkan beberapa hal pokok yaitu (1) KPBU atau PPP adalah bentuk kerjasama pemerintah dan badan usaha dalam penyediaan infrastruktur (2) karakteristik dasar KPBU adalah kerjasama jangka panjang, saling membagi resiko antar para pihak dan para pihak menghasilkan produk (barang atau jasa). (3) Di Indonesia , jenis infrastruktur yang bisa dilakukan KPBU adalah infrastruktur ekonomi dan sosial. (4) Bentuk KPBU atau PPP secara teoritis sangat bervariasi mulai dari) Service Contract and Management Contract sampai pada Private Finance Initiative and Private ownership berserta bentuk turunannya. (5) Faktor faktor penentu kesuksesan implementasi KPBU dapat berupa : Kemampuan Komprehensip KPBU Pemerintah, Kelembagaan Dalam KPBU, Imbalan Bagi Pihak Swasta Yang Menarik, Kepastian Hukum dan Perilaku Oportunistik.

Berdasarkan kesimpulan maka direkomendasikan hal hal sebagai berikut : (1) untuk proyek proyek KPBU yang berdurasi jangka panjang dan memiliki jumlah investasi sangat besar (mega proyek), pemerintah dan pihak swasta harus membuat kontrak jangka panjang, detail dan mampu meminimalkan aspek perilaku oportunistik diantara mereka. (2). Sumber pembiayaan (untuk penyertaan modal) pemerintah pada proyek proyek KPBU sebaiknya dari sumber sumber seperti : obligasi atau surat hutang negara atau pinjaman lunak luar negeri. Ini akan membuat pemerintah berpikir keras untuk menjaga konsistensi pendapatan dari proyek KPBU di masa depan karena adanya unsur pelunasan pinjaman dan bunga. 


\section{DAFTAR PUSTAKA}

Peraturan Kepala Lembaga Kebijakan Pengadaan Barang / jasa Pemerintah (Perka LKPP) no. 19 / 2015 tentang tata cara pelaksanaan pengadaan badan Usaha Kerjasama Pemerintah Dengan Badan usaha Dalam Penyediaan Insfrastruktur.

Peraturan Menteri Perencanaan Pembangunan Nasional/ Kepala Badan Perencanaan Pembangunan Nasional Republik Indonesia Nomor 4 / 2015 Tentang Tata Cara Pelaksanaan Kerjasama Pemerintah Dengan Badan Usaha Dalam Penyediaan Infrastruktur.

Peraturan Presiden No 38 / 2015 tentang Kerjasama Pemerintah Dengan Badan Usaha Dalam Penyediaan Infrastruktur.

Peraturan Menteri Keuangan , No 190/PMK.08/2015 tentang pembayaran ketersediaan layanan dalam rangka Kerjasama Pemerintah dengan Badan Usaha Dalam Penyediaan Infrastruktur.

Mathur Swati, 2014, Public Private Partnership in infrastructure - A study on roads and Highway Project in Andhra Prades, Thesis Doctor Of Philosophy (PhD), Departement of Business management, Osmania University, Hyderabad, Pp. 1-277.

Theodoropoulos, S., Tassopoulos, E. (2014). Public Private Partnership Contracts Financing by Covered Bonds. European Research Studies Journal, 17(3), pp. 17-36

Priya M.Sathana and P.Jesintha, 2011, Public Private Partnership In India, Journal Of Management And Science Vol.1, No.1, September.

Akhmetshina E.R., G.T. Guzelbaeva, D.K. Rakhmatullina, 2017, Special Economic Zone as a Local Area of Public-Private Parthership Implementation, European Research Studies Journal Volume XX, Issue 2A, 2017, pp. $346-354$

Akhmetshina E.R and Mustafin A.N., 2015, Public-private partnership as a tool for development of innovative Economy, Procedia Economics and Finance 24 ( 2015 ) 35 - 40

Carbonara Nunzia, Nicola Costantino and Roberta Pellegrino, 2013, A Three-Layers Theoretical Framework For Analyzing Public Private Partnerships: The Italian Case, organization, technology and management in construction $\cdot$ an international journal $\cdot$ 6(2), pp 799-810

Qizilbash Anis, 2011, Public-Private Partnerships And The Value Of The Process: The Case Of Sub-Saharan Africa, International Public Management Review, Vol. 12, Iss. 2, pp 38-54

Iossa Elisabetta and David Martimort, 2009, The Simple Micro-Economics of Public- Private Partnerships, Working Paper No. 09-03. Pp1-57

Nsasira Rachael, Benon C. Basheka \& Pross. N. Oluka,2013, Public Private Partnerships (PPPs) and Enhanced Service Delivery in Uganda: Implications from the Energy Sector, International Journal of Business Administration Vol. 4, No. 3, PP. 48-60

Jin Xioa-Hua , 2009, Allocating Risks in Public-Private Partnerships using a Transaction Cost Economics Approach: A case study, The Australasian Journal of Construction Economics and Building, Vol 9, No 1, pp. 19-26

Koschatzky Knut, 2017, A theoretical view on public-private partnerships in research and innovation in Germany, Working Papers Firms and Region No. R2/2017. Pp. 1-27

Liu Zhiyong and Hiraku Yamamoto, 2009, Public-Private Partnerships (PPPs) in China: Present Conditions, Trends, and Future Challenges, Interdisciplinary Information Sciences Vol. 15, No. 2 pp. 223-230

Estache Antonio, 2014, Public Private Partnerships and Efficiency: A Short Assessment, EPPP DP No. $2014-06$ pp. $1-12$

Qu Y and Loosemore M, 2013, A meta-analysis of opportunistic behaviour in public-private partnerships: manifestations and antecedents In: Smith, S.D and Ahiaga-Dagbui, D.D (Eds) Procs $29^{\text {th }}$ Annual ARCOM Conference, 2-4 September 2013, Reading, UK, Association of Researchers in Construction Management, 415-424

Kementerian koordinator bidang perekonomian Republik Indonesia, buklet ekonomi Indonesia. Di download, 10 November 2017. 